ISSN 0103-5150

Fisioter. Mov., Curitiba, v. 29, n. 1, p. 61-70, Jan./Mar. 2016

Licenciado sob uma Licença Creative Commons

DOI: http://dx.doi.org.10.1590/0103-5150.029.001.A006

(c)

\title{
Motor performance of HIV-positive children
}

\author{
Desempenho motor de crianças HIV positivas
}

\section{Grazielle Aurelina Fraga-Sousa, Maria Clara Rangel Rodrigues, Marjorie Graziolli Pereira, Tatiana Santos Arruda, Regina Célia Turolla de Souza*}

Universidade Estadual de Campinas, (UNICAMP), Campinas, SP, Brazil

\begin{abstract}
Introduction: Evidence indicates that HIV-positive children have a lower motor performance compared to uninfected children. The analysis of the factors that determine these changes is very important for the implementation of rehabilitation strategies. Objective: To analyze the motor development of seropositive children and compare it to the performance of healthy children with normal neuropsycomotor development. Materials and Methods: Eight children were evaluated, aged between four and six years, divided into two groups: Group I $(n=4)$ composed of HIV-positive children without any secondary disease and Group II ( $n=4)$ composed of healthy children, matched to Group I by sex and age. The Peabody Developmental Motor Scales (PDMS-2) for gross motor function and fine motor function were used to evaluate motor performance. Results: In both groups, most of the children presented an average or above average motor performance, according to normal data of PDMS-2. The analysis indicated no inter-group differences in the gross scores ( $p>0,05$, Mann-Whitney test) or motor quotients ( $p>0.05$, Mann-Whitney test). However, intra-group analysis indicated a marginally significant difference between motor quotients ( $p=0,07$, Wilcoxon test), with higher fine motor quotient in both
\end{abstract}

* GAFS: MSc, e-mail: grazielle_fraga@hotmail.com MCRR: Specialist, e-mail mariaclara_rr@hotmail.com MGP: Specialist, e-mail: marjorie_graziolli@hotmail.com TSA: Specialist, e-mail: tatiana_s_arruda@yahoo.com.br RCTS: PhD, e-mail: reginaturolla@yahoo.com.br 
groups. Conclusion: The data suggest no significant difference between the motor performance of HIV-positive children and healthy children. These results contribute to the analysis of motor development of HIV-positive children, raising questions about factors that may influence the motor development of these children.

Keywords: HIV infections. Child development. Motor function. Physical therapy.

\section{Resumo}

Introdução: Evidências indicam que crianças soropositivas apresentam um desempenho motor inferior ao de crianças não infectadas. A análise dos fatores que determinam essas alterações é de extrema importância para a implementação de estratégias de reabilitação. Objetivo: Analisar o desempenho motor de crianças soropositivas e compará-lo ao desempenho de crianças saudáveis, com desenvolvimento neuropsicomotor normal. Materiais $\boldsymbol{e}$ Métodos: Foram avaliadas 08 crianças, com idade entre 4 e 6 anos, divididas em dois grupos: Grupo I $(n=04)$ composto por indivíduos HIV positivo sem presença de qualquer tipo de doença secundária e o Grupo II ( $n=04)$ composto por crianças saudáveis, pareadas ao Grupo I quanto ao sexo e idade. As escalas de função motora grossa e função motora fina da Peabody Developmental Motor Scales (PDMS-2) foram utilizadas para avaliação do desempenho motor. Resultados: Em ambos os grupos, a maioria das crianças, apresentou desempenho motor na média ou acima da média, segundo os dados normativos da PDMS-2. A análise inter-grupos não indicou diferenças quanto aos escores brutos ( $p>0,05$; teste de Mann-Whitney) ou quocientes motores ( $p>0,05$; teste de Mann-Whitney). Entretanto, a análise intra-grupos indicou uma diferença marginalmente significativa entre os quocientes motores ( $p=0,07$; teste Wilcoxon), com valores mais elevados do quociente motor fino em ambos os grupos. Conclusão: Os dados sugerem que pode não haver diferença significativa entre o desempenho motor de crianças HIV positivo e crianças saudáveis. Estes resultados contribuem para a análise do desenvolvimento motor de crianças soropositivas, levantando questões sobre fatores que podem influenciar o desenvolvimento motor destas crianças.

Palavras-chave: Infecções por HIV. Desenvolvimento infantil. Função motora. Fisioterapia.

\section{Introduction}

Acquired Immunodeficiency Syndrome (AIDS) is caused by infection with the Human Immunodeficiency Virus (HIV), a retrovirus that replicates inside cells of the immune system (1-3). In this process, the cells are destroyed and the capacity of the organism to fight common diseases decreases, leaving the person subject to the onset of opportunistic infections $(4,5)$. It is estimated that in recent years, in the regions of Central America and South America, 92,000 people have been infected with HIV; a third of those were residents of Brazil (6). The incidence rate in Brazil is higher in adults aged 25-49 years, with an increase in this number over the past decade. In such cases, transmission can occur through sexual contact or contaminated blood exposure. In children under five years of age, the major form of transmission is through vertical transmission, namely, from mother to child and can occur during pregnancy, labor and delivery, or or through the breast milk (7).
Brazil reduced the incidence of AIDS in children under five years of age by $49 \%$ from 1998 to 2008 $(1,8,9)$. This decrease is due to the implementation of the Ministry of Health recommendations from the 1990s, specifically for pregnant women with HIV, including: the introduction of antiretroviral therapy, HIV testing and counseling during pregnancy, viral load monitoring and CD4+ cell counts, access to specialized services, as well as guidance related to not breastfeeding in these situations (10).

Neurological disorders are common in HIV-infected individuals, and are attributed to virus action in the central nervous system (CNS) or secondary to opportunistic infections and tumors (11). Children have more complications compared to adults because their brains are under development and therefore are more prone to CNS injuries resulting from an early HIV infection (12). These injuries can be determined by minor symptoms of hyperactivity and irritability, to the most complex pictures of progressive or non-progressive encephalopathy. The presence of calcification in the 
white matter and basal ganglia, by release of pro-inflammatory cytokines and free radical produced by the virus, are one of the possible causes of encephalopathy in HIV-infected children $(12,13,14)$.

Neuropsychomotor developmental delay (NPMD) is a common consequence of encephalopathy, and is more severe in young children between 18-29 months $(13,15)$. A study performed with 173 children with HIV indicated the occurrence of some type of neurological impairment in $67 \%$ of the sample, with NPMD along with language delay, intellectual disability, pyramidal syndrome and hyporeflexia observed more frequently (16).

Another study showed the importance of rehabilitation in motor development when comparing two groups of seropositive children. The group that performed physical therapy for one year had a significant improvement in motor skills compared to the group without stimulation. However, even with the improvement, the experimental group remained with scores below normal levels, indicating a need for continuity of care (17).

In addition to the NPMD, seropositive children may have less muscle trophism and strength in the lower limbs and lower agility when compared to uninfected children (18). These children have calcium deficiencies and alterations in bone development, which interfere with normal growth, and therefore, their neuropsychomotor development $(8,19)$. Leandro \& Merhi, et. al., (20) observed that the occurrence of reduced growth and weight gain can be present in HIV-infected children from the first year of life, being directly associated with reduced survival. The occurrence of lower height and weight may also be observed in children in severe stages of the disease (21).

The neuropsychomotor development occurs through task demands, individual biology and the environment, thus, the acquisition of certain motor behaviors leads to essential repercussions both in their motor and intellectual development $(22,23$, $24,25)$. Along with the maturation of the child into adulthood, achieved by introduction of antiretroviral treatment, some changes in the normal neuropsychomotor development can appear, which can influence education, work and the future social life of these individuals $(26,27)$. Therefore, it becomes extremely important to conduct studies to elucidate these changes, in order to implement rehabilitation methods to prevent the progression of deficits, thereby bringing improvements in motor development and quality of life of these children.

In this context, the aim of this study was to transversely analyze the motor performance of HIVpositive children, and compare it to the performance of uninfected children with normal development.

\section{Material and methods}

This was a cross-sectional study, conducted in the Physiotherapy Clinic in Pediatric Neurology of UNICAMP University Hospital (State University of Campinas - UNICAMP). The sample consisted of eight children of both genders, aged four and six years, which were divided into two groups. For the composition of Group I, children followed at the Pediatric Clinic of UNICAMP University Hospital were recruited, of both genders, aged 0 - 6 years, with HIV by vertical transmission or blood transfusion. Seronegative children, affected by serious illnesses, with cognitive and/or neurological deficits and a hospitalization episode within the past three months were excluded. Group II was composed of healthy children of both genders, born full term with a normal neuropsychomotor development history. These children were recruited at a Kindergarten school of Campinas-São Paulo, being paired to the children from Group I according to gender and age. This group did not include children with a history of neurological, orthopedic or cognitive deficits.

Initially, a patient screening was performed through medical files, according to the inclusion and exclusion criteria described above. Nine children eligible for Group I were recruited, however, only four agreed to participate. The legal guardians of the children in this group were approached during consultation at the Pediatric Clinic of the UNICAMP University Hospital, or contacted by telephone and verbally informed about the research proposal. The same occurred with the participants of Group II, which were subjected to screening within the specific inclusion and exclusion criteria for this group. In this case, the approach occurred during school hours, by letter and/or communication via the school principal. The Terms of Free and Informed Consent was signed by the legal representatives of the children who participated in this study, agreeing with their participation. The research protocol of this study was prepared according to the 
guidelines proposed in Resolution no. 196/96 of the National Health Council on research involving human subjects, and was approved by the Research Ethics Committee of UNICAMP (Protocol no: 497/2011).

The motor performance assessment was performed at a predetermined moment, and the location of the assessment for Group I was the Physiotherapy Clinic in Pediatric Neurology of UNICAMP University Hospital; for Group II, the location was the school environment during class hours, at moments which did not interfere with school activities.

For data collection, in order to characterize the sample in Group I, a card was used with data on the history of the disease, mode of transmission, and medication treatment. The assessment of motor performance was realized by the Peabody Developmental Motor Scales - Second Edition (PDMS - II), whose purpose is to assess fine and gross motor skills, which are developed from birth to six years of age $(28,29)$.

The PDMS - II is composed of two scales for evaluating gross (170 items) and fine (112 items) motor functions. The gross motor function scale consists of four subscales: Reflexes ( 8 items), to evaluate the persistence of primitive reflexes, or the lack thereof; Stationary (30 items), which includes balance and strength in different static postures; Locomotion (89 items), which observes balance and strength in dynamic postures; and Object Manipulation (24 items), which evaluates the handling objects of varying sizes and different distances. A scale of fine motor function consists of two subscales: Grasping (26 items), which examines different types of tweezers and manual coordination; and Visual-Motor Integration (72 items), whose function is to assess eye-hand coordination $(28,29)$.

Each item is adjusted to the age, in an increasing sequence according to the level of difficulty. So, the child begins testing at the point of the scale regarding his age, and each assessment item receives a score of $0-2 ; 2=$ when the task was performed according to the criteria specified in the manual; 1 = performance was similar to the established criteria, but did not totally satisfy it; $0=$ the task cannot be performed. The results can be represented in an overall score, standard score and motor quotient: fine (FMQ), gross (GMQ) and total (TMQ), the latter being the sum of the former $(28,30)$.

The motor assessment was conducted by trained researchers, by using the original PDMS- II materials kit (28). The approximate time to perform a thorough evaluation was 90 minutes.
The collected data were computerized using the SPSS statistical software (version 13.0 for Windows). For descriptive analysis, values for frequency, mean and standard deviation were used. The non-parametric statistics were used for inter-group (MannWhitney test) and intra-group (Wilcoxon test) comparisons, and the significance level was $\mathrm{p} \leq 0.05$.

\section{Results}

Data characterizing the groups according to gender and age are presented in Table 1. In Group I, the transmission of the virus occurred during pregnancy $(\mathrm{n}=2)$ or breastfeeding $(\mathrm{n}=2)$. All children in the group $(n=4)$ received antiretroviral treatment since birth, and more than half $(n=3)$ had a history of hospitalizations.

Table 2 shows the classification of motor performance of the groups in each subscale, according to the normative data present in PDMS - II. Note that most of the subjects showed performance at or above the mean in both the fine motor function and the gross motor function subscale. In Group I, two children (50\%) were classified as below the mean on the Object Manipulation subscale; in Group II, only one child $(25 \%)$ was classified as below the mean on the Locomotion subscale.

Table 1 - Characterization of the groups according to gender and age

\begin{tabular}{lcc}
\hline & Group I $(\mathrm{n}=4)$ & Group II $(\mathrm{n}=4)$ \\
\hline Gender & 3 & 2 \\
\hline Female & 1 & \\
Male & & \\
\hline Age (months) & & \\
\hline Minimum & 64 & \\
Mean ( \pm SD) & $67.25 \pm 3.59$ & $62.25 \pm 6.50$ \\
Maximum & 72 & 68 \\
\hline
\end{tabular}


Table 2 - Classification of motor performance of the groups

\begin{tabular}{|c|c|c|c|c|c|c|}
\hline & \multicolumn{3}{|c|}{ Group I $(n=4)$} & \multicolumn{3}{|c|}{ Group II $(n=4)$} \\
\hline & $\begin{array}{l}\text { Below } \\
\text { mean }\end{array}$ & Mean & $\begin{array}{l}\text { Above } \\
\text { mean }\end{array}$ & $\begin{array}{l}\text { Below } \\
\text { mean }\end{array}$ & Mean & $\begin{array}{l}\text { Above } \\
\text { mean }\end{array}$ \\
\hline Stationary & $0 \%$ & $100 \%$ & $0 \%$ & $0 \%$ & $100 \%$ & $0 \%$ \\
\hline Locomotion & $0 \%$ & $75 \%$ & $25 \%$ & $25 \%$ & $25 \%$ & $50 \%$ \\
\hline Object Manipulation & $50 \%$ & $50 \%$ & $0 \%$ & $0 \%$ & $100 \%$ & $0 \%$ \\
\hline Grasping & $0 \%$ & $100 \%$ & $0 \%$ & $0 \%$ & $100 \%$ & $0 \%$ \\
\hline $\begin{array}{l}\text { Visual-Motor } \\
\text { Integration }\end{array}$ & $0 \%$ & $25 \%$ & $75 \%$ & $0 \%$ & $25 \%$ & $75 \%$ \\
\hline
\end{tabular}

Table 3 shows the comparison between Group I and Group II, in relation to the gross score for each of the motor subscales, without stating statistically significant differences between groups (Mann-Whitney test, $p>0.05$ ).

Table 4 shows the motor quotient data (fine, gross and total) for both groups. Although Group II obtained higher mean scores, there was no significant difference between groups ( $p>0.05$ ).

When analyzing intra-group differences between the FMQ and GMQ, a marginally significant difference $(p=0.07)$ was observed, with higher values for the FMQ in both groups (Figure 1).

Table 3 - Mean and standard deviation values of the gross scores obtained by groups on each PDMS - II subscale

\begin{tabular}{|c|c|c|c|c|c|c|c|}
\hline & & Group I & & & Group II & & $\mathrm{p}$ \\
\hline & Minimum & Mean $( \pm S D)$ & Maximum & Minimum & Mean $( \pm S D)$ & Maximum & \\
\hline Stationary & 53 & $56.5( \pm 2.38)$ & 58 & 53 & $55.25( \pm 3.20)$ & 58 & 0.64 \\
\hline Locomotion & 170 & $174.25( \pm 3.30)$ & 178 & 163 & $171( \pm 7.62)$ & 178 & 0.66 \\
\hline $\begin{array}{l}\text { Object } \\
\text { Manipulation }\end{array}$ & 34 & $40.25( \pm 4.65)$ & 45 & 41 & $43.75( \pm 2.22)$ & 46 & 0.19 \\
\hline Grasping & 52 & $52( \pm 0.00)$ & 52 & 51 & $51.75( \pm 0.50)$ & 52 & 0.32 \\
\hline $\begin{array}{l}\text { Visual-Motor } \\
\text { integration }\end{array}$ & 138 & $141.75( \pm 2.87)$ & 144 & 135 & $141.25( \pm 4.19)$ & 144 & 0.77 \\
\hline
\end{tabular}

Note: Mann-Whitney test. $p>0.05$

Table 4 - Quotients obtained by the groups on the Motor quotient by the PDMS - II in mean value and standard deviation

\begin{tabular}{|c|c|c|c|c|c|c|c|}
\hline & \multicolumn{3}{|c|}{ Group I } & \multicolumn{3}{|c|}{ Group II } & \multirow[t]{2}{*}{$\mathrm{p}$} \\
\hline & Minimum & Mean $( \pm S D)$ & Maximum & Minimum & Mean $( \pm S D)$ & Maximum & \\
\hline GMQ & 85 & $97.5( \pm 9.95)$ & 109 & 87 & 102.25 & 113 & 0.38 \\
\hline FMQ & 100 & $112.75( \pm 9.29)$ & 121 & & $171( \pm 7.62)$ & 178 & 0.66 \\
\hline TMQ & 90 & $104( \pm 10.55)$ & 115 & 106 & $115( \pm 6.00)$ & 118 & 0.88 \\
\hline Grasping & 52 & $52( \pm 0.00)$ & 52 & & $51.75( \pm 0.50)$ & 52 & 0.32 \\
\hline $\begin{array}{l}\text { Visual-Motor } \\
\text { integration }\end{array}$ & 138 & $141.75( \pm 2.87)$ & 144 & 100 & $108( \pm 7.70)$ & 116 & 0.66 \\
\hline
\end{tabular}

Note: GMQ $=$ Gross motor quotient. FMQ $=$ Fine motor quotient. TMQ $=$ Total motor quotient. Mann-Whitney test. $p>0.05$ 


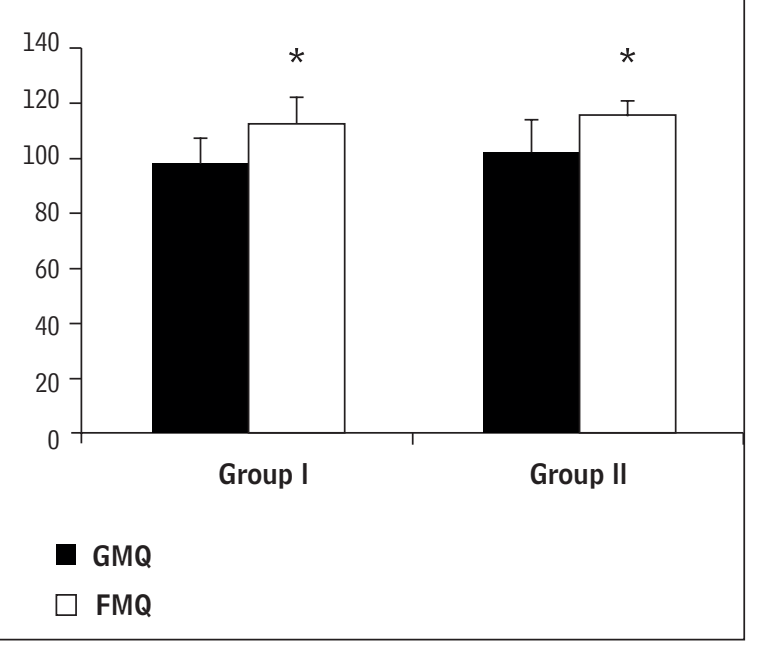

Figure $\mathbf{1}$ - Mean values and standard deviation of the gross and fine motor quotients for both groups. Legend: GMQ = gross motor quotient; $F M Q=$ fine motor quotient. Wilcoxon test, ${ }^{*} \mathrm{p}=0.07$

\section{Discussion}

The data analysis indicated no difference between the motor performance of children with HIV and uninfected children, which disagrees with evidence regarding the occurrence of motor development delay in this population $(13,14,17,20,21,27,31,32)$.

In a study conducted by Smith et al., (33) the PDMSII was used to evaluate the motor development in children with HIV. Data analysis obtained in the first evaluation, performed at two years of age, indicated below average results compared to normal values in the scales of gross and fine motor. However, when the same children were re-evaluated, after 18 months, improvements in gross scores and motor quotients were found, but not enough to equate them to the average healthy children (33). Rie et. al., (15) corroborated this data, concluding that HIV-positive children aged between 18 and 29 months had worse motor performance on the PDMS-II when compared with children aged between 30 and 72 months who were also infected. In the present study, older children were evaluated, with an average of five years, which could suggest an improvement in their motor skills over time, explaining the similarity observed between the groups.

For intra-group comparisons, a marginally significant difference between the FMQ and GMQ was observed, and the FMQ was higher in both groups. According to Smith et. al., (33) this difference could be related to the fact that children with HIV have a higher deficit in some brain areas that act in the control of generalized and conditioning strength. The results of this study, however, suggest that the observed difference can also be found in healthy children, which support the results obtained by Melo (24) when the children's motor profile between three and six years was assessed.

Malnutrition has been identified as a factor that may result in a worsening of motor deficit, and is very common in people with HIV because of malabsorption of nutrients, metabolic imbalance, and poor eating (34). Malnutrition can decrease strength and muscle mass, leading to lower ability to perform physical activities, further slowing the learning of movements $(18,20)$. In this study, the children of the HIV group had good eating habits, proper medical and parental care with regard to food, and lack of exposure to environmental factors considered to be of risk, which may have led to good motor performance in this group.

The negative environmental factors and other adverse comorbidities are equally important in this context (16). Seropositive children living in foster care had a worse performance on the fine motor PDMSII scale, when compared to children living in family homes, which confirms the influence of the external environment on motor acquisition (35). In our sample, participants lived in fixed homes with their parents (biological or adoptive), receiving health care and education, which can have determined positive results.

Neurological deficits are also determining factors for alteration in psychomotor development (21). Most of the research that indicates the occurrence of NPMD in children with HIV, does not specify whether the children who composed the study sample were suffering from neurological diseases or other conditions that may compromise motor development $(14,17,20)$. Other authors, however, claim that the studied children have some form of encephalopathy associated to HIV $(21,27)$. Therefore, the good performance observed among children with HIV, in the current research, can be related to the absence of any secondary disease or neurological deficit that could compromise motor development.

Earlier treatment with antiretroviral medication is also associated with gains in motor and cognitive development (36). According to data collected from the interviews with parents of the children, the study participants received medication and medical care since birth, which may have contributed to a better motor development, reflected in the results of this study. 
Current data indicate a decrease from $16 \%$ to $2 \%$ of vertical HIV infection rate in countries that have intensified care during pregnancy (10). This fact may have contributed to a greater difficulty in selecting children in the age group of interest for this study, even in a reference center in the area (Pediatric Clinic of the UNICAMP University Hospital), in contrast to the large number of infected older children and adolescents.

\section{Conclusion}

In contrast to most studies on the motor performance of children with HIV, the results obtained in this study did not show significant differences in relation to healthy children. These data contribute to the analysis of motor development of children with HIV, suggesting questions about the factors that may disguise the motor performance of these children. Future studies with more expressive samples will contribute to further clarification of the effect of such factors.

\section{References}

1. Bragheto MAC. Crianças Portadoras do HIV/AIDS [dissertation]. Ribeirão Preto: Escola de Enfermagem de Ribeirão Preto da Universidade de São Paulo; 2008.

2. Muller V, Ledergerbe B, Perrin L. Stable virulence levels in the HIV epidemic of Switzerland over two decades. AIDS. 2006; 20(6):889-4.

3. Coffin JM. HIV Population Dynamics in Vivo: Implications for Genetic Variation, Pathogenesis, and Therapy. Science. 1995; 264:483-9.

4. Kaplan JE, Benson C, Holmes KK, Brooks JT, Pau A, Masur H. Guidelines for prevention and treatment of opportunistic infections in HIV-infected adults and adolescents. MMWR Recomm Rep. 2009; 58(RR-4):1-207.
5. Mofenson LM, Brady MT, Danner SP, Dominguez KL, Hazra R, Handelsman E, et al. Guidelines for the Prevention and Treatment of Opportunistic Infections among HIV-exposed and HIV-infected children: recommendations from $C D C$, the National Institutes of Health, the HIV Medicine Association of the Infectious Diseases Society of America, the Pediatric Infectious Diseases Society, and the American Academy of Pediatrics. MMWR Recomm Rep. 2009; 58(RR-11):1-248.

6. Programa Conjunto das Nações Unidas sobre HIV/ AIDS (Unaids). Relatório Global sobre a Epidemia de AIDS. [Cited in 8 jun. 2011]. Available from: http:// www.unodc.org/documents/lpo-brazil//noticias/2010/11/RELAToRIO_MUNDIA L_20101123_ FS_America_Latina_America_do_Sul_csa_em_en_PORT. pdf.

7. CPLP/ONUSIDA. Epidemia de HIV nos países de língua portuguesa: situação atual e perspectivas futuras rumo ao acesso universal à prevenção, tratamento e cuidados. [Cited in 8 jun. 2011]. Available from: http://www.onu-brasil.org.br/doc/VIH_em-paises_ Lingua_Portuguesa_2Edicao-FINAL.pdf.

8. Oliveira HW, Veeck EB, Souza PHC, Fernandes A. Avaliação radiográfica da idade óssea em crianças infectadas pelo HIV por via vertical. Radiol Bras. 2006; 39(1): 27-31.

9. Pacheco Filho RJ, Santos HF. Estudos Brasileiros sobre Demência Associada ao HIV. DST- Jornal Brasileiro de Doenças Sexualmente Transmissíveis. 2008; 20(3-4): 196-203.

10. Luiza MH, Alberto NRJ, Carmen SBD, Heloisa H, Mariliza HS. Relatório do projeto de pesquisa: avaliação da transmissão vertical do HIV no estado de São Paulo, Brasil. São Paulo, Programa Estadual DST/AIDS de São Paulo. 2010. 32p.

11. Gissleân M., Hagberg L. Antiretroviral treatment of central nervous system HIV-1 infection: a review. HIV Medicine. 2001; 2: 97-104.

12. Capelo AV, Sá CAM, Rubini NP, Kalil RS, Miranda E. Impacto da Neuro-AIDS na infância. DST- Jornal brasileiro de Doenças Sexualmente Transmissíveis; 2006. p. 259-62. 
13. Bruck I, Tahan TT, Cruz CR, Martins FTL, Antoniuk AS, Rodrigues M, Souza SM, Bruyn LR. Developmental Milestones of vertically HIV infected and seroreverters children. Arq. Neuro- Psiquiat. 2001; 59(3):691-5.

14. Nozyce ML, Lee SS, Wiznia A, Nachman S, Mofenson LM, Smith ME, Yogev R, Mcintosh K, Stanley K, Pelton S. A behavioral and cognitive profile to clinically stable HIV-infected children. Pediatrics. 2006; 117(3):763-70.

15. Rie AV, Mupuala A, Dow A. Impact of the HIV/AIDS Epidemic on the Neurodevelopment of PreschoolAged Children in Kinshasa, Democratic Republic of the Congo.Pediatrics. 2008; 122 (1):124-8.

16. Rocha C, Gouvêa, Machado D, Cunegundes K, Beltrão S, Bononi F, Succi RC. Manifestações neurológicas em crianças e adolescentes infectados e expostos ao HIV1. Art. Neuro-Psiquat. 2005; 63(3):828-83.

17. Potterton J, Stewart A, Cooper P, Becker P. The effect of a basic home stimulation programme on the development of young children infected with HIV. Dev Med Child Neurol. 2010;52(6):547-51

18. Barros C, Araújo T, Andrade E, Cruciani F, Matsudo V. Avaliação das variáveis de força muscular, agilidade e composição corporal em crianças vivendo com HIV/ AIDS. R Bras Ci e Mov. 2006; 14(4):47-54.

19. O’Brien KO, Razavi M, Henderson RA, Caballero B, Ellis KJ. Bone mineral content in girls perinatally infected with HIV. Am J Clin Nutr. 2001;73:821-6.

20. Lendro-Merhi VA, Vilela MMS, Barros Filhos AAB. Características do crescimento de crianças infectadas com o vírus da imunodeficiência humana. Pediatria. 2001; 1:17-26.

21. Foster CJ, Biggs RL, Melvin D, Walters MD, TudorWilliams G, Lyall EG. Neurodevelopmental outcomes in children with HIV infection under 3 years of age. Dev Med Child Neurol. 2006; 48(8):677-82.

22. Guimarães AF, de Carvalho DV, Machado NÁA, Baptista RAN, Lemos SMA. Risk of developmental delay of children aged between two and 24 months and its association with the quality of family stimulus. Revista Paulista de Pediatria. 2013;31(4):452-458.
23. Willrich A, Azevedo C C F D, Fernandes J O. Desenvolvimento motor na infância: influência dos fatores de risco e programas de intervenção. Rev Neurocienc. 2009; 17(1):51-6.

24. Melo ASL. Influência das variáveis biológicas e socioculturais no perfil motor de crianças dos 36 aos 71 meses. [dissertation] Vila Real: Universidade de Trás os Montes e Alto Douro; 2011.

25. Neto RF. Valoración del desarrollo motor y su correlación com los transtornos del aprendizaje. [thesis] Zaragoza: Faculdade de Medicina - Universidade de Zaragoza; 1996.

26. Gibb D, Duong T, Tookey PA, Sharland M, TudorWilliams G, Novelli V,Butler K, Riordan A, Farrelly L, Masters J, Peckham CS, Dunn DT. Decline in mortality, AIDS, and hospital admissions inperinatally HIV-1 infected children in the United Kingdom and Ireland. Papers. 2003;327: 1019-24

27. Baillieu N, Potterton J. The extent of delay of language, motor, and cognitive development in HIV-positive infants. J Neurol PhysTher. 2008; 32(3):118-21.

28. Folio R, Fewell R. The Peabody Developmental Motor Scales: Examiner's Manual. $3^{\circ}$ ed. Austin: Pro Ed; 2000.

29. Saraiva L, Rodrigues L. Peabody Development Motor Scales (PDMS-2): Validação preliminar para a população pré-escolar Portuguesa. In: 1ํo Congresso Internacional de Aprendizagem na Educação de Infância; 2005; Porto: Escola Superior de Educação de Paula Frassinetti; 2005.

30. Mascarenhas T. Análise das escalas desenvolvidas para avaliar a função motora de pacientes com paralisia cerebral. [dissertation] São Paulo: Faculdade de Ciências Medicas da Santa Casa de São Paulo; 2008.

31. Boivin MJ, Green SDR, Davies AG, Giordani B, Mokili JKL, Cutting WAM. A Preliminary Evaluation of the Cognitive and Motor Effects of Pediatric HIV Infection in Zairian Children. Health Psychology. 1995; 14(1):13-21.

32. Rie AV, Harrington PR, Dow A, Robertson K. Neurologic and neurodevelopmental manifestations of pediatric HIV/AIDS: A global perspective. European journal of paediatric neurology. 2007; 11:1-9. 
33. Smith MR, Danoff JV, Parks RA. Motor Skill Development of Children with HIV Infection Measured with the Peabody Developmental Motor Scales. Pediatr Phys Ther. 2002; 14(2):74-84.

34. Miller TL, Orav EJ, Colan SD, Lipshultz SE.Nutritional status and cardiac mass and function in children infected with the immunodeficiency virus. Am J Clin Nutr. 1997; 66:660-4.

35. Jelsma J, Davids N, Ferguson G. The motor development of orphaned children with and without HIV: Pilot exploration of foster care and residential placement. BMC Pediatric. 2011; 11:11.
36. Rie AV, Dow A, Mupuala A, Stewart P. Neurodevelopmental trajectory of HIV-infected children accessing care in Kinshasa, Democratic Republic of Congo. J Acquir Immune Defic Syndr. 2009; 52(5): 636-42.

Recebido: 30/10/2013

Received: 10/30/2013

Aprovado: 24/06/2015

Approved : 06/24/2015 
